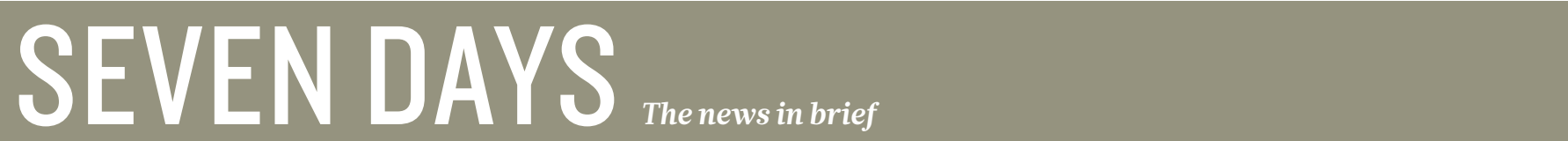

POLICY

\section{Oceans partnership}

A coalition headed by the World Bank hopes to raise US $\$ 1.5$ billion to help to improve the world's oceans. Unveiling the Global Partnership for Oceans in Singapore on 24 February, the bank's president, Robert Zoellick, said that governments, nongovernmental organizations, private companies and United Nations bodies had joined to coordinate their approaches to ocean conservation. Many of the partnership's targets such as rebuilding depleted fish stocks and increasing the number of marine protected areas - mirror existing UN goals. See go.nature.com/ he6ldt for more.

\section{Alzheimer's plan}

The US Department of Health and Human Services has launched a draft action plan to find ways to treat and prevent Alzheimer's disease by 2025 . The plan is part of a concerted effort focusing on Alzheimer's research and care; last month, President Barack Obama's administration told the US National Institutes of Health to reallocate US\$ $\$ 0$ million for the disease from its 2012 budget (boosting its Alzheimer's research funding to $\$ 498$ million), and requested an extra $\$ 80$ million for Alzheimer's research in 2013.

\section{Greek protests}

Demonstrations continued last week against reforms that aim to introduce more meritocracy and accountability into Greece's higher-education system. On 22 February, protesters disrupted elections for governing boards at the University of Crete in Heraklion and at the Athens University of Economics and Business. Elections have

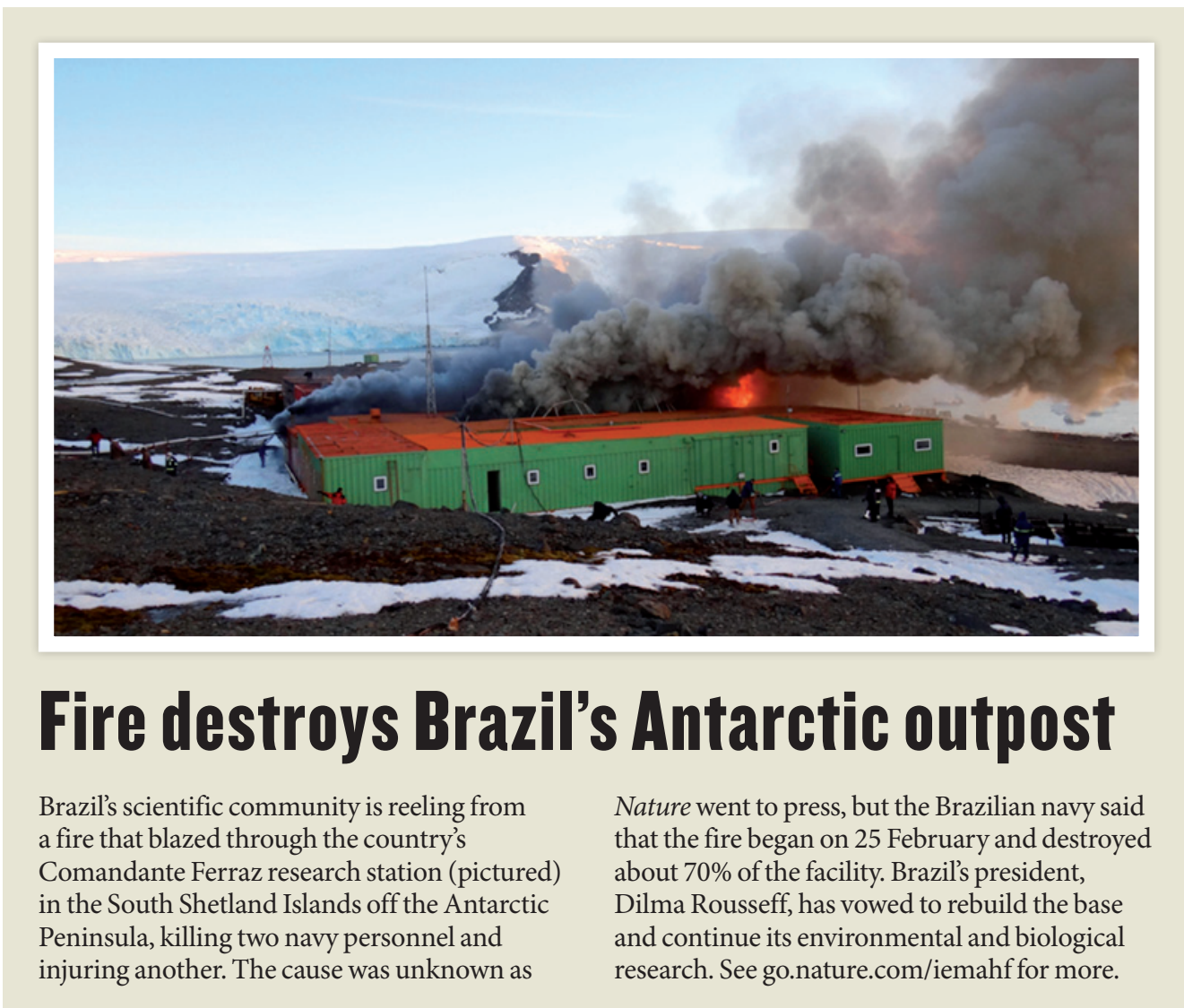

been stopped at four other universities in past weeks, and more are scheduled for March. See page 15 for more.

\section{Publish or perish}

Cost-saving cuts at the University of Sydney, Australia, have triggered a furious backlash, after the university sent letters to around 100 academics last week, sacking them for not publishing frequently enough. Researchers were told that they had been fired because they had not published at least four "research outputs" over the past three years, says Michael Thomson, president of the Sydney branch of the Australian National Tertiary Education Union. The union was disputing the sackings as Nature went to press. See go.nature.com/rohpvo for more.

\section{Tar-sands deadlock}

European diplomats have failed to agree on a measure that would effectively block imports of oil from tar sands in Canada. A vote on 23 February over whether to classify tarsands oil as highly polluting in terms of greenhouse-gas emissions ended in stalemate; environment ministers are now expected to make a decision in June. Europe's fuel directive requires fuel suppliers to cut emissions, so a high emissions rating would in practice shut down the European market for tar-sands oil. See go.nature.com/sejma4 for more.

\section{FUNDING}

\section{Austrian largesse}

Austria's most ambitious research institute yet, the three-year-old Institute of
Science and Technology near Vienna, has secured its long-term future with a funding deal worth up to $€ 990$ million (US\$1.3 billion). On 22 February, the institute announced that its federal and provincial government co-funders would grant $€ 65.8$ million annually between 2017 and 2026, with another $€ 33.2$ million available for reaching agreed researchquality criteria, and for matching external grants won by its scientists. The Austrian Academy of Sciences called the funding "an unjustified privilege”. See go.nature.com/ qiciw5 for more.

\section{Africa eco-network}

In an effort to improve agricultural systems in Africa, researchers in the United States and South Africa have launched an initiative 
to gather and integrate data about ecosystems, farming practices and human wellbeing across the continent. Backed by a US\$10-million grant from the Bill \& Melinda Gates Foundation, the threeyear project is expected to set the stage for a larger global monitoring system, organizers announced on 23 February at a meeting of the International Fund for Agricultural Development in Rome. See go.nature.com/bhbhm3 for more.

\section{RESEARCH}

\section{Too quick, too soon}

Two possible sources of error have been identified in the OPERA experiment, which last September announced that it had timed neutrinos travelling faster than the speed of light. On 22 February, the multinational collaboration announced that the errors related to the Global Positioning System signal used to synchronize the atomic clocks used in the experiment. See page 17 for more.

\section{PEOPLE}

\section{Heartland fallout}

The Pacific Institute in Oakland, California, is investigating its president, Peter Gleick (pictured), after he admitted that he had dishonestly acquired,

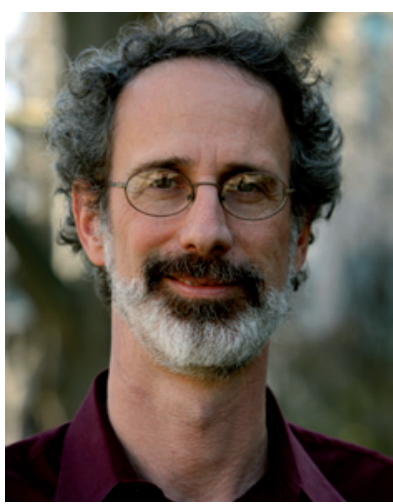

and leaked to the media, internal budget documents from the Heartland Institute, a libertarian think tank in Chicago, Illinois, that aims to combat climate science. On 24 February, Gleick asked for a temporary leave of absence from the Pacific Institute, which he co-founded and has led for 25 years. On the same day, US Congressman Edward Markey (Democrat, Massachusetts) asked the Heartland Institute to confirm which of the documents were authentic.

\section{Plagiarism politics}

C. N. R. Rao, the science adviser to India's prime minister, has found himself embroiled in a plagiarism row, after he failed to notice some copied text in a paper that he had co-authored (B. Chitara et al. Adv. Mater. 23, 54195424; 2011). Three sentences in the introduction and a description of an equation had been copied verbatim from a referenced source. $\mathrm{APhD}$ student, Basant Chitara, says he was responsible for the error. Rao says that the Indian media took a subsequent apology from all the authors to mean that the entire paper had been plagiarized. See go.nature.com/wbckgc for more.

\section{BUSINESS}

\section{Obesity pill}

An advisory panel to the US Food and Drug Administration (FDA) has recommended approving a diet pill that was rejected two years ago because of concerns over its side effects. Qnexa (phentermine plus topiramate) is made by Vivus of Mountain View, California, which saw its share price soar $78 \%$ when the drug received the thumbs-up on 23 February. The FDA is expected to decide on Qnexa by 17 April. If approved, it would be the first new US obesity drug in more than a decade.

\section{Cancer lawsuits}

Cancer geneticist Craig Thompson, head of the Memorial Sloan-Kettering Cancer Center in New York, is being sued by his former employers. The University of Pennsylvania in Philadelphia says that

\section{TREND WATCH}

Two-thirds of the 3.2 million people in the United States living with the hepatitis $C$ virus (HCV) were born between 1945 and 1964. These middle-aged 'baby-boomers' are now reaching the age when $\mathrm{HCV}$-related diseases and deaths start to show up. A study documenting how HCV has overtaken HIV as a cause of death (see chart; from K. N. Ly et al. Ann. Intern. Med. 156, 271-278; 2012) says that better awareness and treatments are needed.

\section{RISING DEATHS FROM HEPATITIS C}

By 2007, hepatitis C infection had surpassed HIV as a cause of death in the United States, a new analysis reveals.

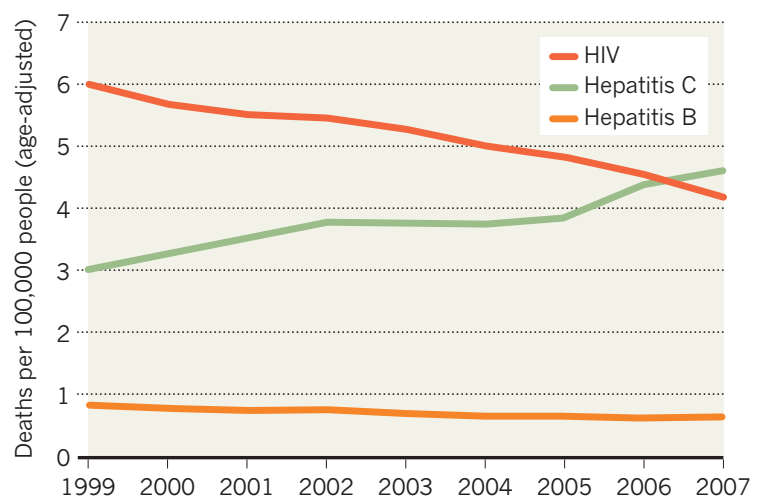

COMING UP

5 MARCH

In New Orleans, Louisiana, a trial begins over who should pay for damages caused by the 2010 oil spill in the Gulf of Mexico. BP may settle some of its costs in advance.

\section{7-8 MARCH \\ The European Space Agency hosts a symposium in Frascati, Italy, on international security - including threats from computer viruses and cyberwarfare. go.nature.com/raj6a5}

Thompson did not disclose research to the university that he later used to form a commercial biotechnology firm, Agios Pharmaceuticals in Cambridge, Massachusetts. The lawsuit, announced on 22 February, is the second against Thompson and Agios: last December, the Abramson Family Cancer Research Institute at the University of Pennsylvania which Thompson previously headed - also sued him for not notifying university officials of his work. Both suits seek damages for the loss of intellectual property.

\section{GM energy crops}

Ceres, a US biotechnology firm that selectively breeds and genetically modifies seeds to grow high-yielding biofuel crops, raised US\$65 million in its initial public offering on 22 February. The firm, based in Thousand Oaks, California, sells sorghum seeds - used to make ethanol - in Brazil and sorghum and switchgrass seeds in the United States. It is $5 \%$ owned by the transgenicseed giant Monsanto, of St Louis, Missouri.

\section{$\rightarrow$ NATURE,COM}

For daily news updates see:

www.nature.com/news 